\title{
Emergency Preparedness - Working in Partnership
}

\author{
by Simon Lewis \\ Head of Emergency Planning and Response - British Red Cross.
}

$\mathrm{I}$ had the immense privilege to provide a presentation of the above title to a conference at the University of St. Andrews in February of this year. The conference, entitled 'Assessing the Emergency Response to Terrorism', was hosted by the University's Centre for the Study of Terrorism and Political Violence (CSTPV).

I am currently the Head of UK Emergency Planning and Response for the British Red Cross. Prior to this I spent over 30 years in the Metropolitan Police Service, the last five of which was as Head of Emergency Preparedness.

This article is based on my presentation and discusses how responders in the UK have learnt from past terrorist activity and built real partnership working and improved interoperability. I use the response to the Terrorist bombings in London on 7th July 2005, as a backdrop.

1973 is a perfect year to start in terms of demonstrating London's improved emergency preparedness. This was the year that the London Emergency Services Liaison Panel (LESLP) was formed. At the time of forming, only the Police, Fire and Ambulance Service were members. These agencies had, at this time, already responded to Irish Republican Terrorism attacks on the UK mainland in the aftermath of Bloody Sunday in 1972. LESLP produced a Major Incident Procedures Manual which detailed the roles and responsibilities of the three emergency services and provided protocols and clear command and control structures.

These command and control structures are based around three main responsibilities: Strategic, Tactical, and Operational, known as Gold, Silver, and Bronze, and are based on role, not rank or grade. These designated roles are intended to be carried out by the most competent person available. This allows organisations to overcome the possible cultural difficulties within some hierarchical organisations which may otherwise specify that a person's grade or rank takes priority. A Gold or Silver designated tabard is usually worn which helps to allow for absolute clarity to colleagues and partner agencies arriving on scene as to roles and responsibilities.

LESLP membership has grown over the years and now includes the Metropolitan Police, City of London Police, British Transport Police, London Fire Brigade, London Ambulance Service, Local Authorities, Port of London Authority, Marine Coastguard Agency, Royal Air Force, Military, and the Voluntary Sector.

LESLP and its Major Incident Procedures Manual are recognised as good practice amongst many responders across many countries. The manual is now in its 7 th edition, recognising minor changes in light of responses since 1973.

It is worth remembering that whilst LESLP and its manual has learnt and grown (in terms of membership, maturity and experience), so have the responders. Responder's experience is something which cannot be taught and has been so vital in improving the way in which emergency 


\section{Journal of Terrorism Research}

planning and response has improved in the UK over many years. The manual can be downloaded from the LESLP website.

Wind the clock forward to the terrorist attacks in the USA in 2001. These events had an understandable impact on how emergency planners and responders worked together in London and the UK. In early 2002 the London Resilience Team was formed made up of senior civil servants and secondees from relevant agencies. These agencies included all those listed under LESLP, above, but with the additions of the National Health Service, the Health Protection Agency, Utility Companies, Transport Organisations, Government, and Business.

This Team was organised into thematic Panels (originally named Sub Committees) and Task and Finish Groups (originally named Working Groups). The thematic Panels included, for example, a Business Panel, Utilities Panel, Voluntary Sector Panel, and Health Panel. The Task and Finish Groups were in place to advice on and write specific plans including, Mass Evacuation, Mass Fatality, Recovery Management, and CBRN (Chemical, Biological, Radiological, and Nuclear).

The Task and Finish Groups and thematic Panels report up to the London Resilience Forum which meets quarterly and is Chaired by The Mayor of London.

There was, and is, a real strength in bringing civil servants and subject matter expert responders, with other relevant partners, together under one roof to concentrate on this important work.

There is benefit in this team meeting so regularly, with its members having had personal experience of developing the plans. This provides true ownership.

To square the circle, this membership, meets in peace time and in time of crisis. The only difference is likely to be the Chair and the title. In times of terrorism the Chair would be a senior police officer and the title would be 'Gold Coordinating Group' or 'Strategic Coordination Group'.

In times of emergency this group would report to COBRA (Cabinet Office Briefing Room), which would be Chaired by the appropriate minister. More information about the London Resilience Team can be found at the London Prepared website.

When the Civil Contingencies Act was created in 2004, the structures and responsibilities mentioned above, including the Local Resilience Forum and the Strategic Coordinating Group, have all been included within the guidance to the Act. www.cabinetoffice.gov.uk/content/civilcontingencies-act

During the morning rush hour of 7th July 2005, the day after London was awarded the 2012 Olympic Games, four terrorist explosions took place in the capital. I had involvement in the management of the police response. Three of these explosions took place on the London Underground system near to Russell Square, Edgware Road, and Aldgate and one took place on a bus in Tavistock Square.

There was an hour between the three subterranean explosions and the explosion on the bus. No one will ever know whether the time difference and range of transport targets was planned or whether the fourth terrorist was excluded from the London Underground when the whole system was evacuated. If the latter was the case, this may then have been the reason to look for alternatives. Further attacks are always a consideration and this device, an hour later, certainly focussed minds.

Having mentioned that the whole London Underground system was evacuated, it is worth pointing out that being the morning rush hour, this meant that approximately 400,000 people were simultaneously spilling out into London's streets. 


\section{Journal of Terrorism Research}

A Gold (Strategic) Coordinating Group (SCG) meeting was called. This took place in the Strategic Coordination Centre. Each member of the meeting, i.e. sitting at the table, was the Gold representative for their organisation/work-stream. Examples include Transport; Utilities; and NHS. Supporting these Gold representatives were an organisation/work-stream cell with phone/internet links to their home organisation(s). Ideally each cell should have live audio/visual coverage of the SCG. Each Gold representative should have a lap top to communicate with their cell. As actions are assigned within the meeting, each cell will then report back, live, with progress on actions.

There are obvious differences for emergency responders when comparing the attack on the London Underground to the attack on the bus. The London Underground, once evacuated, provided a closed scene allowing the emergency service and forensic examiners unfettered access where all forensic exhibits were contained. The fact that the media were excluded also had its advantages. The disadvantage though, was the heat, the dust, communication problems, and the health and safety risks over a protracted period. Using the explosion that took place in-between Russell Square and Kings Cross as an example, it is worth noting that the train was 457 metres from Russell Square Station and 261 metres from Kings Cross. It was also over 21 metres below ground level. This clearly meant that access and egress was a real issue. The bus explosion presented, in some cases the complete opposite. Examples include difficulty in maintaining privacy from media and difficulty in retrieving all forensic exhibits which were spread over a wide area. There was however, far easier access and egress.

One of the plans developed by the London Resilience Team and put into use after the London bombings of 2005 was the Mass Fatality Plan. This facility allowed for post-mortems and the identification process to take place at one site. Great care was taken in the planning and preparation of this facility to provide the highest possible dignity for the dead and the best care, consideration and psycho-social support for the bereaved.

Another facility that was provided but had not been planned for was the Humanitarian Assistance Centre. This was a converted exhibition hall in central London which was equipped with furniture, telephones, computers, internet access, confidential areas for psycho-social advice, catering and signposting. The following agencies, amongst others, contributed to the staffing of this centre: Police (including Family Liaison Officers), British Red Cross and other voluntary sector agencies, Coroner's Officers, Social Services, NHS Mental Health Services, Transport for London, and Victim Support. A Humanitarian Assistance Plan now exists. Other plans developed by the London Resilience Team include a Mass Evacuation Plan, Recovery Management Protocol, a Warning and Informing Strategy, Media Strategy and a Site Clearance Plan.

Since the attack and the emergency response, there have been several reviews and the Coroner's Inquest. These have provided identified lessons and recommendations which will help improve future responses to emergencies of this type.

I would just like to close by recognising the many heroes of 7th July 2005, many of whom were fellow passengers or passing members of the public, many too were emergency responders, all of whom played such a vital part in providing invaluable comfort to individuals and saving life.

About the author: Simon Lewis has been in post as Head of Emergency Planning and Response for the British Red Cross since 2010. His team work with British Red Cross Volunteers and Staff and liaise externally with Government, Police, Fire, Ambulance, Local Authorities and other partner agencies to ensure that the British Red Cross are in the best position to support them in an emergency. 


\section{Journal of Terrorism Research}

Formerly Simon spent over 30 years as a police officer with the Metropolitan Police Service (MPS). In his last 5 years with the police he was Chief Superintendent, Head of Emergency Preparedness at New Scotland Yard. During this time Simon chaired the London Emergency Services Liaison Panel.

Simon was Tactical Commander (Silver) for Trooping the Colour (Her Majesty the Queen's Birthday Parade) in 2006, 2007 and 2008. He spent a period of time as Silver for the London Bombings on 7th and 8th July 2005 and was Tactical Commander for the consequence management issues following the murder of Alexander Litvinenko.

simonlewis@redcross.org.uk

www.redcross.org.uk 